${ }^{\circ}$ Entomologica Fennica. 7 September 1995

\title{
Five species of flies (Diptera) new to Finland, with notes on additional rare species
}

\author{
Antti Haarto
}

\author{
Haarto, A. 1995: Five species of flies (Diptera) new to Finland, with notes on \\ additional rare species. — Entomol. Fennica 6:5-6.
}

Three species of Syrphidae and two species of Calliphoridae are reported as new to Finland, and notes on additional rare species of Syrphidae are given.

Antti Haarto, Kaukonpuistotie 43, FIN-23120 Mietoinen, Finland

Received 1 June 1995, accepted 15 June 1995

\section{Syrphidae}

Metasyrphus abiskoensis Dusek \& Laska - New to Finland

Le: Enontekiö, Kilpisjärvi, Saana, 6.VII.1946, 107. The specimen is preserved in the collection of the Zoological Museum, University of Turku, and is labelled "Saana 6.VII.1946, Reg. Subalp., Geranium". Distribution of the species is northern Europe (Dusek \& Laska 1976).

Platycheirus complicatus Becker — New to Finland *

$L i$ : Utsjoki, Vetsikko (776:51), luxuriant birch forest near a brook, 9.VII.1994, 20', A. Haarto leg. Typical habitat of the species is subalpine birch forest. $P$. complicatus has been earlier recorded from Sweden, Norway and Petsamo area in Russia (Nielsen 1981). At the same place and time, I collected also the northern species $P$. latimanus (Wahlberg) 1Q, and P. hyperboreus Staeger 10'.

Sphaerophoria bankowskae Goeldlin - New to Finland

$A b$ : Mietoinen, Perkko (6733:222), 18.VI.1994, $10^{7}$ A. Haarto leg. S. bankowskae is known from Switzerland, Italy, Sweden (Pajala) and Denmark (Nordmark) (Torp 1994).
Pipizella viduata (Linnaeus)

$O b N$ : Rovaniemi commune, Apukka (738:45), 18.VI.1974, 4O'2Q and 21.VI.1974, 3Q. ObN: Rovaniemi commune, Olkkajärvi, Laita-aapa (738:45), 16.VI.1975, 20'1 $q, 17$. VI.1975, $1 \%$ and 23.VI.1976, 20, O. Osmonen \& A. Valmari leg. $O b N$ : Rovaniemi commune, Jorvanaapa (738:44) 16.VI.1976, 10', O. Osmonen leg. The material was collected from cloudberry (Rubus chamaemorus) and is preserved in the Zoological Museum, University of Turku.

$P$. viduata was earlier reported from northern Finland as $P$. varipes Meigen by Hippa et al. (1981). Also Torp (1994) indicated that the species occurred in Finland (source of this information is unkonwn), but Silfverberg $(1986,1991)$ did not include this species in the additions to the Finnish insect fauna.

\section{Sphaerophoria fatarum Goeldlin}

$O b N$ : Rovaniemi commune, Olkkajärvi (738:45), 5.-14.VI.1975, ca. 40 exx, O. Osmonen \& A. Valmari leg.; $O b N$ : Rovaniemi commune, Olkkajärvi, Laita-aapa (738:45), 16.-23.VI.1975, ca. 80 exx, and 4.-23.VI.1976, ca. 80 exx, O. Osmonen \& A. Valmari leg.; ObN: Rovaniemi commune, Olkkajärvi Räättiaapa (738:44), 10.-

* Editorial note: Conspecific material identified in 1985 by T. Nielsen from $L i$, Utsjoki, Coll. Frey, exists in the collections of the Zoological Museum, University of Helsinki (Ståhls pers. comm.); it is not known whether this record has been published earlier. 
16.VI.1976, ca. 10 exx, O. Osmonen leg. The material was collected from cloudberry (Rubus chamaemorus) and is preserved in the Zoological Museum, University of Turku.

Hippa et al. (1981) reported this species as $S$. abbreviata Zetterstedt from $\mathrm{Li}$ : Utsjoki Kevo Shirrajärvi (774:49). It was also recorded from Finland by Hedström (1991), but was not included in the additions to the Finnish insect fauna by Silfverberg $(1986,1991)$, and not reported from Finland by Torp (1994).

\section{Sphaerophoria virgata Goeldlin}

$O b N$ : Rovaniemi commune, Olkkajärvi, Laitaaapa (738:45), 23.VI.1976, $10^{7}$ O. Osmonen leg. The specimen was collected from cloudberry (Rubus chamaemorus) and is preserved in the Zoological Museum, University of Turku.

Torp (1994) recorded $S$. virgata from Finland, but the source of this information is unknown.

\section{Calliphoridae}

Melinda gentilis Robineau-Desvoidy - New to Finland

$A b$ : Mietoinen (6733:222), 23.V.1994, 10', A. Haarto leg. The habitat was mixed forest where the main tree is Picea abies. Ab: Kaarina, Rauhalinna (6708:247), 9.IX.1994, $10^{7}$ V.-M. Mukkala leg. The species is common in Denmark, widespread in southernmost parts of Norway, and in Sweden spread north up to the province of $D l r$ (Rognes 1991).

Oenesia floralis Robineau-Desvoidy - New to Finland

$A b$ : Korppoo (6684:195), 19.VII.1994, 1Q, A. Haarto leg. The habitat was a moist meadow, with abundant vegetation of Filipendula ulmaria. The species is common in Denmark, as well as in southern Sweden up north to the province of $U \mathrm{pl}$ (Rognes 1991).

\section{References}

Dusek, J. \& Laska, P. 1976: European species of Metasyrphus: key, descriptions and notes (Diptera, Syrphidae). Acta Entomol. Bohemoslov. 73:263-282.

Hedström, L. 1991: Svenska insektfynd - rapport 7. Entomol. Tidskr. 112:133-146.

Hippa, H., Koponen, S. \& Osmonen, O. 1981: Flower visitors to the cloudberry (Rubus chamaemorus L.) in northem Fennoscandia. - Rep. Kevo Subarctic Res. Stat. 17:44-54.

Nielsen, T. 1981: Studies on Platycheirus Lepeletier \& Serville: P. complicatus Becker, P. latimanus (Wahlberg) and $\mathrm{P}$. boreomontanus nom. nov. (Diptera: Syrphidae). - Entomol. Scand. 12:99-102.

Rognes, K. 1991: Blowflies (Diptera, Calliphoridae) of Fennoscandia and Denmark. - Fauna Entomol. Scand. 24:1-272.

Torp, E. 1994: Danmarks svirrefluer (Diptera: Syrphidae). - Danmarks Dyreliv 6:1-490.

Silfverberg, H. 1986: Additions to the Finnish insect fauna during the years 1981-1985. - Notulae Entomol. 66:131-152.

- 1991: Changes 1986-1990 in the list of Finnish insects. — Entomol. Fennica 2:9-17. 